\section{The Birth of Belgian Surrealism: Excerpts from Correspondance (1924-25)}

INTRODUCTION, TRANSLATION, AND COMMENTARY BY JAN

BAETENS AND MICHAEL KASPER

JAN BAETENS is professor of literary and cultural studies at the University of Leuven. His work on early-twentieth-century literature is part of a Leuven research network, MDRN (www.mdrn.be). His most recent book is Pour le roman-photo (Les Impressions Nouvelles, 2010).

MICHAEL KASPER is an emeritus librarian at Amherst College; a book artist, whose dozen titles include Kirghiz Steppes (Black Scat, 2013) and Open-Book (Ugly Duckling, 2010); and a translator from French (Gabriel Pomerand, Louis Scutenaire) and German (Paul Scheerbart).

\section{Introduction}

\section{CORRESPONDANCE WAS A BELGIAN SURREALIST MAGAZINE, FROM THE}

\section{EARLIEST YEARS OF THE MOVEMENT, THAT CAN BE READ AS A CHAL-}

lenge to the notions of surrealism promoted in André Breton's Manifesto of Surrealism of 1924. It was a self-published periodical comprising twenty-two one-page tracts, written and distributed over seven months in 1924 and 1925 by three francophone Belgian writers, Paul Nougé, Camille Goemans, and Marcel Lecomte. The most important of these was undoubtedly the one who published least: Nougé, the intellectual leader of the Brussels surrealist group. In addition to scattered publications of startling originality throughout the 1920s and 1930s, he was at that time also a key promoter of René Magritte's art; at weekly meetings of the group (whose members had day jobs and could only gather on Sunday), Magritte's latest paintings were discussed, and Nougé, mostly, proposed their enigmatic titles.

The short, dense texts of Correspondance critiqued contemporary literary personalities, tendencies, and events: for instance, a public lecture in Brussels, the serialization of a novel by André Gide, or the publication of a questionnaire on modernism (an event that may have launched the whole enterprise). Each issue, a single sheet (A4 size, approximately $8 \frac{1}{4} \times 11 \frac{314}{4}$ inches), was mailed to around a hundred recipients (not always the same list), thus making the project an early example of correspondence art or mail art: direct, anticommercial, inbred, and also visual, since the tracts were printed on and named for paper of different colors and were typeset, sometimes eccentrically, in a modernist font. Correspondance was also ahead of its time in its extensive use of literary collage; a line can be traced from Nougé's practice of plagiarizing and theorizing about plagiarism, throughout his career, through détournement, the situationist concept, to ideas of appropriation popular in writing of the past few decades. Since the archives of the periodical have been lost, the names of the recipients can only be guessed, but they certainly included major Parisian surrealist authors, such as Breton, Louis Aragon, and Paul Éluard, as well as other modernist writers, like Gide, Valery Larbaud, and Jean Paulhan, the most important literary broker in France in

(C) 2013 JAN BAETENS AND MICHAEL KASPER

PMLA 128.2 (2013), published by the Modern Language Association of America 
the interwar period and the editor then of La nouvelle revue française (NRF).

In the absence also of any manifesto, the concrete mission of the Correspondance tracts must be inferred from close readings of the texts; it seems plausible to suppose that the authors' intention was to practice, if not invent, a new form of criticism that was more direct and more disquieting than previous forms, especially for those who were the objects of the Correspondance critiques. Throughout the series, the authors didn't merely express literary opinions; they hoped to develop a new way of using literature, as a means of cultural as well as political action. The relation between writing and action, and more generally between art and life, was of course a basic preoccupation of all the avant-gardes of the period, but the rejection of institutionalized literature and ways of publishing was stronger in Brussels than in, say, Paris, where Breton and his friends, after all, were deeply involved in the literary and fine arts marketplaces.

Like French surrealism, Belgian surrealism was profoundly marked by Dada and the revolutionary spirit of the post-World War I years. In other meaningful respects, though, these two surrealisms diverged. Belgian avant-garde culture has been routinely called surrealist ever since the 1920 s, but the core of this movement-namely, the Brusselsbased Correspondance group-remained ambivalent about the very word surrealism to the end.

From the start it was clear that the Correspondance authors had a distinct vision of surrealist writing and of the relation between literature and politics in the context of an intentionally revolutionary surrealism. On the one hand, the Brussels group adopted an especially rationalist stance toward the act of writing: it had to be the result of a lucid decision, a reaction to a stimulus, as efficient as possible. Hence their skepticism toward automatic writing (see Red 16), psychoanalysis, and the fascination with the occult and their refusal to pursue quasi-magical found objects (objets trouvés), like the ones in Breton's Nadja (1928). Instead of these, Nougé and his friends proposed "disruptive objects" (objets bouleversants) - consciously constructed texts, photographs, performances, and paintings aiming to upend expectations. Prime examples are the nineteen amazing captioned photographs made by Nougé between 1929 and 1930, first published in 1968 and now more widely known from La subversion des images, a huge exhibit on surrealist film and photography at the Centre Georges Pompidou in 2010 (in fact, the show's title was borrowed from Nougé's title for those photos [Bajac and Chéroux]).

On the other hand, the Brussels group sought throughout the 1920s and 1930s to design and demonstrate a unique, utopian artistic program within a global revolutionary perspective. Close to the Communist Party and in later years sympathetic to Stalin (certainly in the case of Nougé), they tried to maintain a position that rejected autonomy as well as heteronomy: literature and visual art were not seen as autonomous arts (as in modernism), since their aim was to serve the revolution; but neither could they be heteronomous (as in the Parisian acceptance of party oversight), since any directly political instrumentalization of literature and art would inevitably entail a destruction of their revolutionary potential.

Though short-lived and low-profile, Correspondance was a subtly influential intervention in twentieth-century culture. It is little known nowadays - not surprising given its intentionally marginal publication history, its elliptical style and obscure content, and its origin far from Paris, the center of French writing - but worthy of wider recognition. The selection here attempts to provide a representative sample of the stylistic, rhetorical, and ideological tone of Correspondance, while suggesting as well, although many of its allusions are still open to rediscovery and interpretation, the way the periodical was intimately networked with the wider modernist scene of the mid-1920s.

We have followed the facsimile edited by Paul Aron (Correspondance), whose comments were indispensable during our translation. Finally, we would like to express our most sincere thanks to the copyright holders who generously authorized the publication of this translation: Pierrette Broodthaers and SABAM Belgium (for Nougé's writings) and CamilleGregor Goemans (for Goemans's writings). 


\section{RESPONSE TO A QUESTIONNAIRE ON MODERNISM}

1 One conquers the world, one dominates it, one uses it; thus, quiet and proud, a beautiful fish circles in this bowl.

2 One conquers the word, it dominates you, one is used; thus, quiet and proud ...

3 Then a difficulty arises, so great is the pain of not understanding one another.

"With unforeseen words, on purpose

We ward off what's customary"

One might blush to recognize them trapped in the "passionate safety" of so wholesome a modernism.

Rest assured, they soar, still free.

4 Watching games of chess, or ball, or the seven arts may amuse us a bit, but the emergence of a new art is hardly our concern.

Art, anyway, has been demobilized, what matters is to live.

Rather, life, says the voice from across from us.

We continue our stroll, releasing, as we go, a few differences from the snares we'd set.

5 It has become too easy now to find in all this nothing but a guilty use of space, of a moment, of our heart. It's a youthful vice that asserts itself when neglected. It threatens to blow us away.

6 Since there's still time to do so, we'll take our leave, if you don't mind.

No doubt we'll be back -- elsewhere.

"Correspondance"

PAUL NOUGÉ

226, rue de Mérode, Brussels 


\section{Commentary}

The European avant-gardes between 1910 and 1930 extensively used dialogic literary genres-pamphlets, manifestos, questionnaires, agitprop interventions in the public or the semipublic sphere, performances, readings. Some of the best and most theoretically central work of that era was produced in these forms. Readers, viewers, and listeners were transformed from abstract entities into participants (sometimes willingly, sometimes not), and good art was that which succeeded in provoking an echo.

Blue 1 is dated two weeks after the first issue in the 1924-25 series of 7 Arts, the leading modernist weekly in Belgium then (and, incidentally, a week before the first issue, in Paris, of La révolution surréaliste). 7 Arts had previously circulated a questionnaire on the international situation of modernism. Although the questionnaire has been lost, it is possible to infer from some of the answers that were published later in 7 Arts that Blue 1 is responding to this inquiry. Instead of answering the questions directly, though, Nougé is obscure. Apparently modest in leaving the initiative, the questioning, to others, he in fact adopts a more aggressive stance, if subtly. By erasing the questions and playing with the answers, he perverts the logic of question and answer and turns his replies into interrogations.

Thus, according to the critic Paul Aron (Correspondance; "Les tracts" 178-79), answer 4 deforms and supplements the published response from the peripatetic modernist designer Friedrich Kiesler (1890-1965). In answer 3, the artist and scholar Marcel Mariën notes (59), Nougé intensifies the dialogue with 7 Arts by quoting from Camille Goemans's first poetry collection, Périples, and from a sarcastic review of it in the recent issue of 7 Arts, which describes Goemans's work as exhibiting a "passionate safety."

Nougé further challenges the normal, dialogic "contract" implicit in questionnaires by responding to an audience larger than the pollsters. He addresses not just the 7 Arts group, whose modernism the Correspondance writers considered traditional, but also the Parisian surrealists (whom they also criticized, for different reasons), and a sure sign of that intention is that the tract's last word"elsewhere"-is also that of André Breton's Manifesto of Surrealism (1924). 


\section{SOCRATES'S DELIRIUM}

Socrates: That's why, for the time being, I don't much care. Or, rather . . . Phaedrus: Finish your sentence.

Socrates: "Finish" . . . you're right . . . though if there were still time left, wouldn't that be precisely the thing to avoid? To finish, Phaedrus, maybe one should say to finish off?

Phaedrus: Which demon is suddenly troubling you, Socrates, unlike your usual one?

Socrates: Oh too loyal Phaedrus!

Phaedrus: Oh most secretive of masters! What are you suggesting? Where are you leading me, with your exquisite speech, - and bewildering wisdom . . .

Socrates: May it bewilder you to the point of distrust. This dangerous speech, this dream of movement . . . Alas, even Socrates should mistrust it!

Phaedrus: Ah, cruel friend! You've reserved for me a second agony, a second death. Socrates: Listen. Remember, these geometricians and their artificial or too material rigor; this phony elegance leading one figure to another, and even more, in order to finally choose the one that was longed for, whose image and all of whose reasons one possessed, - this feigned progress in which it is advantageous to discern naught but an equal and unsurprising return trip . . . well, Phaedrus? Isn't this how it failed invincibly, that which you imagined arising from my profound absences? Consider, Phaedrus, such pure spurting, which subsides, of course, and the fatal attraction. l've unveiled and affirmed: no geometry without words. Scant ecstasy; implacable, oh ravenous certainty! But who then might have notified me, Diocles's friend, that I would come to find strange all words that neither implied nor were imprisoned by some sort of geometry? So that at the end of . . . Phaedrus: However, Socrates, following that example, your words have constructed something, they've created something, and knowledge . . . But l've lost track, Socrates ... .

Socrates: . . . at the end of my false adventure, and at what a ridiculously low price, didn't I dispose of everything one is supposed to achieve! Oh yes, knowledge and construction are thus unfortunately confounded; I built for myself, I locked myself in, blind as I was I went around and around in my roomful of words; and in this invisible prison, healed of my hazards, long before the hemlock . . .

Phaedrus: Stop, impious man, you've told the truth, your otherworldly speechmaker ominously burnishes our destitute shadows; for this reprehensible behavior, may the gods confound him, he who dictated to you those perfect architectural discourses...

Socrates: Too perfect, no doubt. But don't accuse him, imprisoned as he is, like you yourself, in the opaque clarity of his own speeches, forever a prisoner, -- like Socrates, when the one who is training him now abandons him for some unforeseen game, or for ...

PAUL NOUGÉ

"Correspondance"

226, rue de Mérode, Brussels 


\section{Commentary}

Nougé had a high regard for Paul Valéry (1871-1945), the eminent poet and essayist, who played a paramount role in the dialogue between tradition and the avant-garde in the 1920s. Valéry's work, today somewhat hastily called neoclassic (or even retroclassic), reflected all the many ambiguities and ambivalences of its author and the crosscurrents of his time. One of Valéry's major traits, which no doubt influenced his initial sympathy for the surrealist movement in general and Breton in particular, was his "terrorism" (in the sense coined by Paulhan [Les fleurs]). A ruthless disparager of literary illusions (inspiration, identification, emotion, fictionality, etc.), Valéry was committed to a cerebral use of literature. Having begun his career with an essay on Leonardo da Vinci, he developed a strong interest in the analogies between science and literature, which he elaborated in diaries, essays, and literary creations.

In White 7, Nougé continues Valéry's "Eupalinos ou l'architecte" ("Eupalinos; or, The Architect"), the first of two Platonic dialogues published in Paris in 1923, revising and resituating phrases from the original. Mariën informs us that the size of Valéry's text, which contains 115,800 characters, had been arbitrarily imposed by the journal that had commissioned it (67). Nougé's intervention not only quotes and transforms lines from Valéry's text, in typical Correspondance fashion, but also continues it. This apparently simple strategy appears more complex as one realizes that the status of an artwork's final form and the relation between perfection and closure are themes central to Valéry's text and Nougé's continuation.

In an in-depth analysis of White 7, Philippe Dewolf describes the shift from Valéry to Nougé:

The protagonists [of Valéry's piece] are Socrates and Phaedrus of Myrrinontes, who, both dead, meet again in the kingdom of shadows. Phaedrus recalls the reflections he exchanged with the architect Eupalinos of Megara. In "Eupalinos" Valéry affirms in a way the superiority of the artist over the philosopher as far as the capacity for achieving a definitive and thus finished form is concerned. Nougé would actually complete Valéry's dialogue by imagining Socrates's Delirium, which became the subject of the tract White 7. It consists of a series of thirteen exchanges, the first of which is in response to Phaedrus's final words in Valéry's "Eupalinos": "That's exactly what immortality is made of." To which Nougé answers, through his character Socrates, "That's why, for the time being, I don't much care."

For Dewolf the philosophical and aesthetic dialogue between Socrates and Phaedrus concerns most of all the problem of concluding: whereas Phaedrus is forever looking for closure, Socrates will resist it, pointedly refusing to finish his sentences... Dewolf further suggests that Nougé proposes an unusual Socrates, one closer to his Sophist enemies than we are used to, and thus indirectly but critically charges Valéry with speechifying and overstating distinctions between artists and philosophers. 


\section{SOME INQUIRIES INTO THE CONSCIENCE OF CONRAD'S HEROES}

One really can't help noticing that the manner in which Mr. Albert Saugère approaches Dostoevsky seems rude. At the least it's a solid approach, and one can doubt neither its benefits nor its range.

We may have the impression that Conrad's characters are created especially to attract interest, to be better known. Mr. Albert Saugère no doubt thinks so, since he knows those of Dostoevsky so well.

"Conrad always reserves for feeling a sense of disquiet, which shows responsibility, contrary to most novelists, who are tempted to ascribe to feelings an irresponsible face."

“These heroes would lack nothing if they didn't lack themselves. Consequently, the plane of agony is displaced ..."

And thus one can take pleasure, a curious pleasure perhaps, in making contact with so much otherness. But with such a sensation, wouldn't it also be a matter of excessive clairvoyance? One is well versed in embarrassment.

MARCEL LECOMTE.

"Correspondance"

226, rue de Mérode, Brussels 


\section{Commentary}

The December 1924 issue of the NRF is an homage to Joseph Conrad, who had died that summer. A contribution by Albert Saugère compares Conrad and Dostoevsky, focusing on character development in ways Lecomte, hostile to psychological criticism, found ridiculous.

Throughout the series, there is a difference in tone and thus in meaning between Lecomte's evaluations and those of Nougé and Goemans. Lecomte's style is less dense than theirs, and his general preoccupations seem less political. Such differences may explain his eventual exclusion from the group.

Typical of Lecomte, Pink 12 is pedestrian and unprovocative. In an interview, Mariën provides a portrait of Lecomte that is reveal- ing on this point. Having explained Lecomte's presence in the Correspondance group by his early interest in Dadaism and surrealism, Mariën stresses Lecomte's old-fashioned poetical stance:

$[\mathrm{H}] \mathrm{e}$ lived his poems. He was inside his poems. He wrote poems, he published them, he corrected them, then republished them.... He lived intensely. He was a poet who believed himself something other than a poet. Imagine, a poet in the full professional sense of the word, one who is interested in nothing but poetry. That was the kind of poet he was. Yet at the same time he thought he was something else. Linked to the mysteries of the universe.

(qtd. in Bussy 173) 


\section{ABOUT A DEATH, THE LIVING, AND THE DEAD \\ “. . . the affirmation of this psychological positivism, of this modern classicism ...."}

from the start, they're planning to give us the sensation of disgrace without cure. From every angle, they watch whatever tries to escape disaster, they require, apparently, that nothing remain that doesn't resemble a corpse.

Already they're describing, "bearing witness to" - a tomb they're seemingly sealing up.

By dint of these sudden brutalities, and the loathing one can taste in them, perhaps we should, with a little less rancor, distinguish a comedic manner: a few who are nothing but rude corpses, noisy, and who surround and celebrate the sad simulacrum they just erected.

They're pleased to recognize it. To recognize themselves. Thus they condemn themselves, with a severity that relieves us of the obligation to intervene.

We return to the one who managed to defend himself against their approach, and to ourselves, whom we sense to be troubled, surprised in the act of catching him at the end of a string of abstract thoughts, for want of two or three certainties. He got away from them nonetheless, incapable as they were of conjuring an interior debate wherein we'd want to meet him at his best.

But these getaways, these returns, will we deplore his failure to secure all the benefits that one supposes they have?

"Understanding oneself and understanding mankind are the only occupations that give meaning to life." He never stops banging his head against this illusory obstacle.

Hence, a game so badly played that one thought it lost - but so much care taken to safeguard his meager opportunity, and such firmness of scruples and diligence,

we must eventually admit how deeply his activities touch us and the dangers he exposes while thus brushing past his end.

That he gets really lost, how can one believe that? How can one neglect an adventure that's constantly on the verge of routing and confounding the intellectual tracery with which he dreams of besieging it, of announcing its unfolding.

Would we consent to death's depriving us of those who permit us to hold out hope for some surprise, some serious menace?

PAUL NOUGÉ.

"Correspondance"

226, rue de Mérode, Brussels 


\section{Commentary}

White 13 is Nougé's commemoration of Jacques Rivière (1886-1925), writer, critic, and editor of the NRF, who had just died. The tract anticipates the homage in the April issue of the NRF that had been announced in March by Paulhan, who had replaced Rivière. Paulhan's editorial ends with the words "Understanding oneself and understanding mankind are the only occupations that give meaning to life" ("Jacques Rivière" 259).

In addition to Paulhan, Nougé quotes Benjamin Crémieux (1888-1944)-literary critic at the NRF, where Crémieux had just

published the first study on Proust-while expressing contempt for what Dewolf calls the "necrophiliac celebrations" surrounding Rivière's premature death (16). The rejection of personality cults is a recurrent trait in Nougé's work and life and one of the main causes of tension between the Parisian and Brussels surrealists. And in White 13, by nodding to the classical (Rivière) and the modern (Paulhan), as well as the avant-garde (Breton, although not explicitly named here, was certainly one of the addressees), Nougé demonstrated that evenhandedness and refusal to worship idols. 


\section{ABOUT A CONCEPT \\ FROM MR. VALERY LARBAUD}

"There is the expression of a much felt sensation, the result of an experiment done often by many of us ..."

it seems as if one has reason to fear such an encounter, since even so much happiness can't stop Logan Pearsall Smith's pretty poem in its tracks. With what curious embarrassment it is mixed, with what weight a delicate thought is weakened:

one imagines the fresh air of freedom, the color of the sentiment that would see it relieve itself of that burden.

Mr. Valery Larbaud's fortune depends on all this, or seems to, as does the reader's (this ideal reader whom he follows through every ordeal)

and this promised land, this land of dreams they reach together. So much so that one doubts, now that one knows it so well, now that one is actually touching its boundaries, whether it's necessary or even possible to see in it anything but a kind of reflection, the real face of departure.

Thus, certain differences, this gulf separating reader from author: it deepens from so many habits, and one experiences their disappointing effects.

Wherever one still feels pleased to believe oneself covered by them, one walks half naked. In truth, they lay bare some secret delusion, the lapse of those accustomed to placing undeserved confidence in the ordinary resources of the mind.

Yet they gain an immobile air from it, the vanity of conversation, and this mediocre taste for a life led by halves to consent to death.

CAMILLE GOEMANS.

"Correspondance"

226, rue de Mérode, Brussels 


\section{Commentary}

Valery Larbaud (1881-1957) was a poet, novelist, and translator, a key figure in European modernism, thanks not only to his workspoetry, essays, and fiction-but also to his exceptional commitment to exchange among European literatures. He was an editorial adviser for the $N R F$ and himself editor of several important journals, among them Commerce (1924-32, with Paul Valéry and Léon-Paul Fargue as coeditors). Heir to an immense fortune, he lived a life of luxury, but also of poor health, in spas in Italy and Spain.

Among many other works, he wrote a celebrated essay entitled "Ce vice impuni, la lecture" ("That Unpunished Vice, Reading," published in Commerce in summer 1924), which Goemans here quotes at the outset and then proceeds to debate. Goemans denounces, among other things, the pseudoproximity of author and reader, one of the salient traits of Larbaud's poetics. Larbaud thought of his writings as conversations or correspondence with his (bourgeois) readers. Many of his works are epistolary in form.

Larbaud's essay title, "Ce vice impuni, la lecture," is a phrase from Trivia (1902), a collection of short prose by the Anglo-American author Logan Pearsall Smith (1865-1946), published in a French version in 1921 (with an introduction by Larbaud). 


\section{REFLECTIONS, SOTTO VOCE}

For A. B.

The mistrust that writing inspires in us never ceases to get mixed up most curiously with a sense of its virtues, which we can't help acknowledging. There's no doubt that it possesses a singular aptitude for keeping us in that fertile zone, in danger, repeatedly in peril, the only place where we can hope to live.

Every day one remarks the way in which writing can guarantee the endless state of war we must maintain within us, around us.

We owe to mistrust in writing our extreme experiences of temptation, as well as certain means for keeping it in check.

This precarious turn, this equivocal approach, a cunning humility, -- is there any other reason to stay faithful to it?

... One can act in such a way as to believe here in a breach of trust, in the customary cruelties of a language invoked naively.

One might imagine an essential doubt arising, and an urge to grab hold of oneself, as of an object, so as to be reassured of one's own existence. At that moment the most secret intentions must emerge, those determined by precious uncertainties. It's mildly reassuring to undertake an inner voyage as in a world of immobile forms and colors. Soon none of them can fail to be recognized. Finally one stops when everything is named, when one can reread oneself like a page of writing.

If the tragedy that one suspected passes these obstinately pursed lips, if it plays out at last in the deceptive light of unreserved confessions, how then can one not be moved?

Surprise of the sort offered by language, some ill-conceived habit might intervene.

Should we be thinking about unlucky audacity, about revolts with no future?

"Words have a way of being grouped according to particular affinities whose general effect is to make them re-create the world on its old model."

Still, such clairvoyance is proof, no doubt, of some profound, unforeseeable rupture.

PAUL NOUGÉ.

"Correspondance"

226, rue de Mérode, Brussels 


\section{Commentary}

"A. B.," the dedicatee, is André Breton. For many commentators on Correspondance, among them Mariën, this is one of the most significant tracts of the series.

It was first closely analyzed in 1984 by Léon Somville, who points to the disagreement over automatic writing as the main cause of dissension between the Parisian and Brussels surrealists, an assessment nowadays accepted by most scholars. In his reading, Somville follows a double thread. On the one hand, he identifies what he calls "machination" (417), a strategy in which Nougé sets a trap for meaning in order to consciously, purposefully generate new meanings. On the other hand, Somville defines Nougé's main rhetorical device as an ironic quotation that twists the sense of its source.

Near the end of Red 16, Nougé quotes from Breton's essay on dream objects, "Introduction au discours sur le peu de réalité" ("Introduction to a Discourse on the Paucity of Reality," first published in Commerce in summer 1924), but in such a way that Breton's sentence, originally part of a defense of automatic writing, can as well be read as a rationale for Nougé's (and Brussels surrealism's) alternative method of constructing disturbing verbal objects, with intention. Breton and Nougé later returned to the debate on automatic writing, the latter to reiterate his position, the former to nuance his. 


\section{TO DIE OF NOT DYING BY PAUL ELUARD}

One imagines Paul Eluard discovering himself in his poems, finding in a close relationship with words the power to defend himself against them, and with what movement, with what intensity, poetry takes form for him. In such a way that one notices much more how his efforts clear a path, pierce the blinding burst of words, discard what tends to separate him from himself, and from us. If he remains an unblemished crystal that some cannot, at least, or dare not look at without emotion, it is nevertheless the case that no shadow is cast through it onto his character, except theirs, which could quickly disfigure it.

From such a set of sentiments, it would perhaps be hazardous to infer the effects of his constructions. And we don't make such poems together, nor, it seems, by virtue of some inverted operation.

One supposes that only fatigue, or maybe an accident, could put an end to any discovery here, could bury what Paul Eluard considers poetry, mysterious, genuine, eternal.

Wherein one recognizes an opinion astonishing for its simplicity, at the same time as a certain capital scorn, and the danger there might be, one day, of clearly distinguishing them.

Thus, certain preoccupations, a current of anxiety, if, however, one doesn't take care of a more direct concern about the future, about a slightly brutal return to the past, it will probably happen that one will precede them with an observation so perfect that tact will demand its correction later. And one should bear in mind the ravenous haste of certain souls, the state of indifference they can attain all at once, it seems . . .

CAMILLE GOEMANS.

"Correspondance"

226, rue de Mérode, Brussels 


\section{Commentary}

Mourir de ne pas mourir ("To Die of Not Dying") is the title of a collection of poems by Paul Éluard, published in 1924. Goemans here follows one of Nougé's challenges to Breton with his own critique of an-

\section{Works Cited and Background Sources}

Allmer, Patricia, and Hilde Van Gelder, eds. Collective Inventions: Surrealism in Belgium. Leuven: Leuven UP, 2007. Print.

Aron, Paul, ed. Correspondance. Bruxelles: Devillez, 1993. Print.

tyles 8 (1991): 1-300. Web. 21 Mar. 2013. Separate section on Nougé, with articles by Daniel Laroche, Michel Biron, Michel Otten, and Madeleine Frédéric.

—. "Les tracts de Correspondance ou les détours d'une stratégie subtile." Soncini Fratta 171-99.

Bajac, Quentin, and Clément Chéroux, eds. La subversion des images. Surréalisme, photographie, film. Paris: Centre Pompidou, 2010. Print.

Breton, André. "Manifesto of Surrealism (1924).” Manifestoes of Surrealism. Trans. Richard Seaver and Helen R. Lane. Ann Arbor: U of Michigan P, 1969. 3-47. Print.

Bussy, Christian. Les surréalistes au quotidien. Paris: Les Impressions Nouvelles, 2007. Print.

Canonne, Xavier. Surrealism in Belgium, 1924-2000. Bruxelles: Mercatorfonds, 2007. Print.

De Naeyer, Christine. Paul Nougé et la photographie. Bruxelles: Devillez, 1995. Print.

Dewolf, Philippe. "Paul Nougé et Correspondance." Courrier du Centre International d'Études Poétiques 208 (1995): 7-24. Print.

Gonzalez, Ana. "Le surréalisme à la belge." Histoire de la littérature belge, 1830-2000. Ed. Jean-Pierre Bertrand, Michel Bion, Benoît Denis, and Rainier Grutman. Paris: Fayard, 2003. 305-13. Print.

Home, Stewart. Neoism, Plagiarism and Praxis. Edinburgh: AK, 1995. Print.

Levy, Silvano. "Paul Nougé and Surreal Invention." New Comparison 17 (1994): 120-37. Print.

Mariën, Marcel. L'activité surréaliste en Belgique (19241950). Bruxelles: Lebeer-Hossmann, 1979. Print. other leading Parisian surrealist. The attack against "transparency" can be read as a continuation of Red 16's refutation of automatic writing. The tone, however, is less provocative than Nougé's.
Matthews, J. H. "Paul Nougé: Intellect, Subversion, and Poetic Language.” Symposium 24.4 (1970): 365-79. Print.

Michel, Geneviève. "Le détournement: De Paul Nougé aux situationnistes." Les chemins du texte: IV Colloquio da APFFUE 1 (1998): 330-42. Print.

—. Paul Nougé. La poésie au cœur de la révolution. Bruxelles: PIE, 2011. Print.

Nougé, Paul. L'expérience continue. Bruxelles: Les Lèvres Nues, 1966. Print.

—. Histoire de ne pas rire. Lausanne: L'Âge d'Homme, 1980. Print.

—_ La subversion des images. Bruxelles: Les Lèvres Nues, 1968. Print.

Paulhan, Jean. Les fleurs de Tarbes; ou, La terreur des lettres. Paris: Gallimard, 1941. Print.

. "Jacques Rivière." Nouvelle revue française Mar. 1925: 257-59. Print.

- "Les revues." Nouvelle revue française Feb. 1925: 256. Print.

Quaghebeur, Marc. "Evidence et occultation de Paul Nougé.” Fragments. By Paul Nougé. Bruxelles: Labor, 1983. 231-56. Print.

Smolders, Olivier. Paul Nougé. Écriture et caractère à l'école de la ruse. Bruxelles: Labor, 1995. Print.

Somville, Léon. "Belgique." Histoire. Ed. Jean Weisgerber. Budapest: Akadémiai Kiadó, 1984. 410-26. Print. Vol. 1 of Les avant-gardes littéraires au XXe siècle.

Soncini Fratta, Anna, ed. Paul Nougé, pourquoi pas un centenaire? Actes du Colloque Nougé à l'Université de Bologne. Bologna: Cooperativa Libraria Universitaria, 1997. Print.

Vilar, Pierre, ed. Les surréalistes belges. Spec. issue of Europe 912 (2005): 3-266. Print.

Welch, Chuck, ed. Eternal Network: A Mail Art Anthology. Calgary: U of Calgary P, 1995. Print. 